\title{
Pengembangan Modul Praktikum Kinetika Enzim Berbasis Inkuiri Terbimbing untuk Meningkatkan Hasil Belajar Mahasiswa
}

\author{
Nadia Amida ${ }^{1 *}$, F.M. Titin Supriyanti ${ }^{2}$, Liliasari $^{2}$ \\ ${ }^{1}$ Pendidikan Kimia, Universitas Bengkulu, Bengkulu 38371 \\ ${ }^{2}$ Departemen Pendidikan Kimia, Universitas Pendidikan Indonesia, Bandung 40154 \\ *Email: nadia.amida@unib.ac.id
}

DOI: https://doi.org/10.33369/pendipa.5.1.10-14

\begin{abstract}
This study aims to develop a guided inquiry-based enzyme kinetics module in biochemistry practicum to improve student learning outcomes. This study uses the Research and Development (R\&D) method with stages: needs analysis, development of module design, designing module as a research product, validation of module and revisions, and also apply them on small scale. Development of module design based on needs analysis. The designing module as a research product, preliminary research is carried out first which aims to determine the best conditions of the enzyme kinetics experiment. The development of the enzyme kinetics module based on guided inquiry has an average CVR value of 0.92 with a very worthy category. Based on the results of the module assessment sheet, it can improve student learning outcomes in the medium category with a value of $N$-gain of 0.53 .
\end{abstract}

Keywords: Module, Enzyme Kinetics, Guided Inquiry, Experiment of Biochemistry.

\begin{abstract}
ABSTRAK
Penelitian ini bertujuan untuk mengembangkan modul kinetika enzim berbasis inkuiri terbimbing pada praktikum biokimia untuk meningkatkan hasil belajar mahasiswa. Penelitian ini menggunakan metode Research and Development (R\&D) dengan tahapannya: analisis kebutuhan, pengembangan desain modul, desain modul sebagai produk penelitian, validasi modul serta revisi, dan uji coba produk skala kecil. Modul dikembangkan berdasarkan analisis kebutuhan. Pada tahap pengembangan desain, dilakukan terlebih dahulu penelitian pendahuluan yang bertujuan untuk menentukan kondisi terbaik dari eksperimen kinetika enzim. Pengembangan modul kinetika enzim berbasis inkuiri terbimbing memiliki nilai rata-rata CVR sebesar 0,92 dengan kategori sangat layak dan berdasarkan hasil lembar penilaian modul tersebut dapat meningkatkan hasil belajar mahasiswa pada kategori sedang dengan nilai rata-rata $\mathrm{N}$-gain sebesar 0,53 .
\end{abstract}

Kata kunci: Modul, Kinetika Enzim, Inkuiri Terbimbing, Praktikum Biokimia.

\section{PENDAHULUAN}

Salah satu praktikum yang dilakukan dalam perkuliahan yaitu praktikum biokimia. Praktikum biokimia merupakan matakuliah wajib pada program studi kimia jenjang S1 di perguruan tinggi. Tujuan dari mata kuliah ini memantapkan pemahaman konsep-konsep dasar biokimia, dan mengembangkan keterampilan laboratorium. Berdasarkan hasil wawancara yang dilakukan dengan dosen biokimia pada salah satu perguruan tinggi negeri di Bandung, praktikum yang ada saat ini semi-eksperimen dengan model inkuiri terbuka. Pada praktikum yang semieksperimen menggunakan model inkuiri terbuka, mahasiswa melakukan optimasi untuk menentukan kondisi terbaik dari laju reaksi enzimatis yakni kinetikanya. Kinetika enzim terkait dengan uji kualitatif laju reaksi yang dikatalisis oleh enzim. Analisis kinetik memungkinkan untuk merekontruksi jumlah dan urutan tahap-tahap yang merupakan perubahan substrat oleh enzim menjadi produk. Dalam 
menentukan rekontruksi jumlah dan urutan tahap-tahap kinetika enzim sulit dilakukan oleh mahasiswa menggunakan inkuiri terbuka. Hal ini terjadi karena mahasiswa tidak memiliki pengalaman dalam berinkuiri terbuka serta tidak mampu memahami tujuan praktikum, hal ini mengakibatkan mahasiswa cenderung menghapal langkah kerja yang sudah ada. Berdasarkan fakta tersebut, perlu dilakukan bimbingan terhadap mahasiswa dengan menggunakan model inkuiri terbimbing.

Pada model inkuiri terbimbing, praktikum yang dilakukan mahasiswa berbasis pada penemuan, dirancang sesuai dengan permasalahan yang ada, mahasiswa melakukan analisis data dalam membangun hubungan antara variabel, dan membuat kesimpulan sendiri. (Gaddis dan Schoffstall, 2007; Amida, 2018) sehingga dengan adanya inkuiri terbimbing ini praktikum yang dilakukan mampu mengembangkan kemampuan analisis, proses kognitif dan proses sosial yang lebih baik dibandingkan dengan inkuiri terbuka (Xu dan Talanquer, 2013). Dengan adanya tahapan inkuiri terbimbing, akan menciptakan lingkungan yang memotivasi mahasiswa untuk belajar aktif dengan memberikan kesempatan bagi mereka untuk membangun makna serta menemukan konsep, sehingga membangun kerangka berpikir tingkat tinggi dan melatih keterampilan dalam eksperimen (Gaddis dan Schoffstall, 2007; Bailey dkk, 2012; Simonson dan Shaddle, 2013; Fakayode, 2014; Amida, 2017).

Praktikum kinetika enzim yang dilaksanakan menggunakan material lokal. Material lokal yang digunakan meliputi 3 jenis terung yaitu terung ungu, terung hijau, dan terung bulat. Penggunaan material lokal sebagai sumber enzim polifenol oksidase (PPO). Penelitian pendahuluan dilakukan untuk menentukan kondisi terbaik dari enzim. dimana hasil dari penelitian pendahuluan digunakan sebagai dasar praktikum bagi mahasiswa. Pada penelitian ini, dikembangkan modul praktikum pada kinetika enzim yang dapat meningkatkan hasil belajar mahasiswa.

\section{METODE PENELITIAN}

Penelitian ini menggunakan metode Research and Development (R\&D). Dengan tahapan sebagai berikut:
1. Tahap analisis kebutuhan Tahapan ini dimulai dengan menganalisis kegiatan praktikum biokimia

2. Tahap pengembangan desain modul

Tahapan ini diawali dengan menentukan kondisi terbaik dari enzim yang menggunakan material lokal digunakan sebagai dasar praktikum kinetika enzim bagi mahasiswa.

3. Desain Modul sebagai hasil penelitian Hasil dari tahapan analisis yang dilakukan sebelumnya diimplementasikan dalam modul praktikum kinetika enzim berbasis inkuiri terbimbing.

4. Validasi modul

Kegiatan ini untuk menilai keefektifan rancangan produk. Pada penelitian ini validasi produk dilakukan 3 orang ahli yang penilaian nya mencakup kepada materi, media dan kesesuaian model dengan modul.

5. Revisi

Pada tahapan ini dihasilkan modul yang perbaikan nya sudah disesuaikan dengan hasil validasi sebelumnya.

6. Uji Coba Produk

Pada tahapan ini dilakukan uji coba produk pada skala kecil. Implementasi uji coba praktikum kinetika enzim dilakukan menggunakan modul kinetika enzim berbasis inkuiri terbimbing. Dari hasil uji coba produk skala kecil dilihat hasil belajar mahasiswa.

Instrumen yang digunakan untuk pengumpulan data dan pengembangan modul eksperimen adalah tes. Teknik analisis data yang digunakan adalah teknik analisis deskriptif dan kuantitatif

\section{HASIL DAN PEMBAHASAN}

Data yang diperoleh pada penelitian ini meningkatkan hasil belajar mahasiswa pada eksperimen kinetika enzim menggunakan modul berbasis inkuiri terbimbing adalah sebagai berikut:

\section{Analisis kebutuhan}

Berdasarkan hasil wawancara, praktikum biokimia yang dilakukan menggunakan model inkuiri terbuka, dimana mahasiswa hanya melakukan optimasi untuk menentukan kondisi terbaik. Namun hal ini sulit bagi mahasiswa, karena kurangnya pengalaman dalam berinkuiri terbuka dan tidak semua 
mahasiswa mampu memahami tujuan praktikum yang dilakukan sehingga mahasiswa cenderung mengingat langkah kerja yang sudah ada. Berdasarkan hal tersebut, perlu dilakukan inkuiri terbimbing bagi mahasiswa, dimana eksperimen yang dilakukan berbasis pada penemuan, dirancang sesuai dengan permasalahan yang ada, mengumpulkan data pada variabel tertentu, melakukan analisis data dalam membangun hubungan antara variabel-variabel tersebut, dan membuat kesimpulan sendiri.

2. Tahap pengembangan desain modul

Pada tahap pengembangan desain, dilakukan terlebih dahulu penelitian pendahuluan yang bertujuan untuk menentukan kondisi terbaik dari eksperimen kinetika enzim. Hasil dari penelitian pendahuluan akan digunakan sebagai dasar eksperimen bagi mahasiswa. Eksperimen kinetika enzim terkait dengan uji kualitatif laju reaksi enzimatis. Enzim yang digunakan dalam eksperimen yakni enzim polifenol oksidase (PPO). Enzim PPO diperoleh dari bahan alam yang ditemui dalam kehidupan sehari-hari atau dikenal dengan material lokal. Material lokal yang digunakan dalam eksperimen yaitu terung ungu, terung hijau, dan terung bulat.

Ada 8 tujuan dari eksperimen kinetika enzim yang dilakukan yaitu 1) mengisolasi enzim PPO dari material lokal, 2) menentukan jenis substrat, 3) menentukan konsentrasi enzim optimum pada konsentrasi substrat yang tetap, 4) menentukan konsentrasi substrat optimum pada konsentrasi enzim yang tetap, 5) menentukan pengaruh suhu terhadap laju reaksi enzimatis PPO, 6) menentukan pengaruh $\mathrm{pH}$ terhadap laju reaksi enzimatis PPO, 7) menentukan inhibitor yang paling berpengaruh terhadap laju reaksi enzimatis PPO, 8) menentukan jenis inhibisi yang terjadi pada reaksi enzimatis PPO.

Desain modul berbasis inkuiri terbimbing dimulai dengan memberikan fenomena kehidupan sehari-hari yang berhubungan dengan kinetika enzim. Fenomena dimulai dengan pertanyaan "Pernahkah anda memperhatikan perubahan yang terjadi ketika sayuran dan buah-buahan dikupas?". Berdasarkan pengamatan yang anda lakukan, fenomena apakah yang dapat ditemukan? Tuliskan secara jelas!"

Setelah mengemukakan fenomena, mahasiswa akan membuat rumusan masalah, hipotesis serta merancang percobaan sendiri serta menuliskan data pengamatan untuk dikaitkan dengan teori yang berhubungan.

Hasil penelitian pendahuluan pada eksperimen kinetika enzim menggunakan material lokal dapat dilihat pada Tabel 1.

Tabel 1. Hasil penelitian pendahuluan pada eksperimen kinetika enzim

\begin{tabular}{|c|c|}
\hline Eksperimen & Hasil \\
\hline $\begin{array}{l}\text { Isolasi Enzim dari } \\
\text { material lokal : } \\
\text { (a) Terung ungu, } \\
\text { (b) terung hijau, } \\
\text { (c) terung bulat }\end{array}$ & $\begin{array}{l}\text { Warna larutan pada } \\
\text { masing-masing } \\
\text { ekstrak enzim: } \\
\text { Terung ungu : hijau } \\
\text { kekuning-kuningan } \\
\text { Terung hijau : hijau } \\
\text { Terung bulat : hijau }\end{array}$ \\
\hline $\begin{array}{l}\text { Penentuan jenis } \\
\text { substrat }\end{array}$ & $\begin{array}{l}\text { Jenis substrat yang } \\
\text { paling tepat untuk } \\
\text { masing-masing } \\
\text { ekstrak enzim sama, } \\
\text { yaitu katekol }\end{array}$ \\
\hline $\begin{array}{l}\text { Penentuan konsen- } \\
\text { trasi substrat }\end{array}$ & $\begin{array}{l}\text { Konsentrasi substrat } \\
\text { optimum sama untuk } \\
\text { semua jenis ekstrak } \\
\text { enzim yaitu pada } \\
\text { konsentrasi } 0,01 \mathrm{M} \\
\text { (Penambahan } 6 \mathrm{~mL} \\
\text { substrat katekol pada } \\
4 \text { mL ekstrak enzim) }\end{array}$ \\
\hline $\begin{array}{l}\text { Penentuan konsen- } \\
\text { trasi enzim }\end{array}$ & $\begin{array}{l}\text { Konsentrasi enzim } \\
\text { optimum sama untuk } \\
\text { semua jenis ekstrak } \\
\text { enzim yaitu pada } \\
\text { konsentrasi 5,01x } 10^{5} \\
\text { ppm (Penambahan } \\
6 \mathrm{~mL} \text { ekstrak enzim } \\
\text { pada } 4 \text { mL katekol) }\end{array}$ \\
\hline Pengaruh $\mathrm{pH}$ & $\begin{array}{l}\text { pH optimum } 7 \text { untuk } \\
\text { semua jenis ekstrak } \\
\text { enzim }\end{array}$ \\
\hline Pengaruh suhu & $\begin{array}{l}\text { Suhu optimum } 37^{\circ} \mathrm{C} \\
\text { untuk semua jenis } \\
\text { ekstrak enzim }\end{array}$ \\
\hline Penentuan inhibitor & Inhibitor yang paling \\
\hline
\end{tabular}




\begin{tabular}{|c|c|}
\hline & $\begin{array}{l}\text { mempengaruhi laju } \\
\text { reaksi enzimatis PPO } \\
\text { yaitu EDTA untuk } \\
\text { semua ekstrak enzim }\end{array}$ \\
\hline $\begin{array}{l}\text { Penentuan jenis } \\
\text { inhibisi }\end{array}$ & $\begin{array}{l}\text { Jenis inhibisi non- } \\
\text { kompetitif }\end{array}$ \\
\hline
\end{tabular}

3. Desain modul sebagai hasil penelitian Hasil dari tahapan analisis yang dilakukan sebelumnya diimplementasikan dalam modul eksperimen kinetika enzim berbasis inkuiri terbimbing. Produk dikembangkan berdasarkan pada langkah inkuiri terbimbing Kerangka modul yang digunakan mengandung unsur-unsur berikut:

- Fenomena

- Rumusan masalah

- Hipotesis

- Rancangan eksperimen dan data pengamatan

- Diskusi dan analisis data

- Pertanyaan

Modul praktikum dilengkapi dengan rubrik lembar penilaian pada masing-masing tahapan. Lembar penilaian digunakan untuk menentukan hasil belajar mahasiswa.

4. Validasi Modul

Berdasarkan hasil penelitian diketahui bahwa rancangan modul kinetika enzim berbasis inkuiri terbimbing menurut penilaian validator dari segi materi, media, dan kesesuaian model dengan modul memiliki kualifikasi sangat layak dan dapat digunakan dalam praktikum biokimia. Presentase validasi menggunakan nilai CVR (Content Validity Ratio) dapat dilihat pada Tabel 2 .

Tabel 2. Hasil uji validasi modul kinetika enzim berbasis inkuiri terbimbing

\begin{tabular}{ccc}
\hline Validator & Nilai CVR & Kategori \\
\hline 1 & 0,90 & Sangat layak \\
\hline 2 & 0,91 & Sangat layak \\
\hline 3 & 0,93 & Sangat layak \\
\hline
\end{tabular}

\section{Revisi}

Rancangan modul kinetika enzim berbasis inkuiri terbimbing telah dievaluasi oleh 3 orang validator. Secara keseluruhan tidak perlu dilakukan revisi. Namun, revisi tetap dilakukan berdasarkan saran yang diberikan setiap ahli baik yang disampaikan secara langsung maupun secara tertulis yang ada di kolom saran. Modul kinetika enzim berbasis inkuiri terbimbing kemudian dicetak dan diimplementasikan dalam praktikum biokimia.

6. Uji coba produk

Pada tahapan ini dilakukan uji coba produk pada skala kecil. Uji coba dilakukan pada 19 orang mahasiswa pendidikan kimia. Berdasarkan angket yang disebar setelah uji coba produk diperoleh hasil bahwa 100\% mahasiswa dapat mengamati secara langsung hubungan kinetika enzim dalam kehidupan sehari-hari, mengikuti semua arahan yang diberikan oleh dosen, dan membuat laporan sesuai dengan hasil temuan dalam eskperimen kinetika enzim.

Hasil yang cukup rendah yakni $44 \%$ terdapat pada bagian memiliki pandangan yang berbeda dengan teman-teman saya dalam menentukan hubungan kinetika enzim dalam kehidupan sehari-hari, menemukan pemecahan masalah dengan segera saat ada kendala dalam eksperimen yang saya lakukan, dan menganalisis data yang diperoleh selama eksperimen kinetika enzim.

Hasil belajar mahasiswa mengalami peningkatan dengan rata-rata nilai $\mathrm{N}$-gain sebesar 0,53. Penjabaran peningkatan untuk masing-masing kategori dapat dilihat pada Tabel 3.

Tabel 3. Rata-rata nilai N-gain mahasiswa

\begin{tabular}{cc}
\hline Kategori & Nilai N-gain \\
\hline Tinggi & 0,75 \\
\hline Sedang & 0,52 \\
\hline Rendah & 0,15 \\
\hline Rata-rata & 0,53 \\
\hline
\end{tabular}

Dengan menggunakan modul kinetika enzim berbasis inkuiri terbimbing terdapat peningkatan nilai rata-rata mahasiswa sebesar 0,75 pada kategori tinggi. Hal ini karena modul dikembangkan sesuai dengan tahapan nya, dimana mahasiswa mencari lebih banyak pengetahuan yang berhubungan dengan kinetika enzim dengan kehidupan sehari-hari pada tahapan menemukan fenomena, menemukan hubungan fenomena dengan materi, membuat hipotesis, serta merancang sendiri percobaan 
yang akan dilakukan untuk disajikan datanya agar dapat dimengerti.

\section{KESIMPULAN}

Pengembangan modul kinetika enzim berbasis inkuiri terbimbing memiliki nilai ratarata CVR sebesar 0.92 dengan kategori sangat layat dan berdasarkan hasil lembar penilaian modul tersebut dapat meningkatkan hasil belajar mahasiswa pada kategori sedang dengan nilai rata-rata $\mathrm{N}$-gain sebesar 0,53 .

\section{DAFTAR PUSTAKA}

Amida N, F.M.T Supriyanti, Liliasari, (2018). Eksperimen kinetika enzim menggunakan model inkuiri terbimbing untuk meningkatkan keterampilan berpikir kreatif mahasiswa. Alotrop, Jurnal Pendidikan dan Ilmu Kimia, 2018: 2(1): 72-77.

Amida N, F.M.T Supriyanti, Liliasari. (2017). Experiment of enzyme kinetics using guided inquiry model for enhancing generic science skills. IOP Conf. Series: Journal of Physics, 812, (2017), 012063.

Bailey C.P., Minderhout V., dan Loertscher L. (2012). Learning transferable skills in large lecture halls: implementing a pogil approach in biochemistry. Biochemistry and Molecular Biology Education, 40, (1), hlm. 1-7.
Fakayode, S.O. (2014). Guided-inquiry laboratory experiments in the analytical chemistry laboratory curriculum. Anal Bioanal Chem. 406, hlm. 1267-1271.

Gaddis B.A., dan Scoffstall A.M. (2007). Incorporating guided-inquiry learning into the organic chemistry laboratory. Journal of Chemical Education. 84, (5), hlm. 848851.

Simonson S.R, dan Shadle S.E. (2013). Implementing process oriented guided inquiry learning (POGIL) in undergraduate biomechanics: lessons learned by a novice. Journal of STEM Education, 14, (1), hlm. 56-62.

Voet D dan Voet J.G. (2011). Biochemsitry 4th Edition. United States of America: John Wiley \& Sons, Inc.

Wenning Carl J. (2011a). The levels of inquiry model of science teaching. J. Phys. Tchr. Educ. Online, 6(2), Summer 2011. hlm. 916.

Wenning Carl J. (2011b). Levels of inquiry model of science teaching: learning sequences to lesson plans. J. Phys. Tchr. Educ. Online, 6(2), Summer 2011. hlm. 17-20.

Xu H., dan Talanquer V. (2013). Effect of the level of inquiry on student interactions in chemistry laboratories. Journal Chemical Education. 90, hlm. 29-36. 